\title{
AS ONDAS RENOVATÓRIAS DO PROCESSO, NEOCONSTITUCIONALISMO E PROCESSO DEMOCRÁTICO NO NOVO CÓDIGO DE PROCESSO CIVIL
}

\author{
LAS OLAS DEL RENOVACIÓN DEL PROCESSO, NEOCONSTITUCIONALISMO \\ Y EL PROCESO DEMOCRÁTICO EN EL NUEVO CÓDIGO DE PROCESO CIVIL
}

\author{
Marcos Paulo Andrade Bianchini ${ }^{1}$ \\ Alderico Kleber De Borba ${ }^{2}$
}

\section{RESUMO}

O presente trabalho tem por escopo a análise das ondas renovatórias do processo, do neoconstitucionalismo e do processo democrático no novo código de processo civil. Na elaboração do presente trabalho utilizou-se os métodos dedutivo, dogmático e bibliográfico. Valeu-se do processo metodológico histórico e comparativo. Divide-se a pesquisa em três partes fundamentais: ondas renovatórias do processo, contraditório tridimensional e processo democrático no Novo Código de Processo Civil - NCPC. Atualmente a terceira onda renovatória do processo traz questões novas que merecem reflexão, dentre elas o NCPC, que consagrou a aplicação do contraditório em sua visão tridimensional conhecimento-reaçãoinfluência. O direito ao contraditório é o fundamento para decisões democráticas. O NCPC fixou parâmetros para nortear a atividade judicial, estabelecendo um núcleo mínimo de conteúdo quando da prolação de decisões judiciais, positivando a fundamentação analítica, indispensável ao estado democrático de direito e ao devido processo legal, uma vez que concretiza um dos escopos do contraditório tridimensional - o direito das partes de influenciar a decisão. Referida fundamentação, além de impedir o arbítrio, coaduna com o princípio da eficiência, aprimorando e qualificando o direito fundamental da motivação dos atos judiciais, conforme artigo 93, inciso IX, da Constituição Federal. Toda essa evolução contribui sobremaneira para a democratização do processo.

As ideologias do processo democrático no NCPC, somadas ao princípio do contraditório em sua visão tridimensional, bem como a fundamentação legítima e qualificada das decisões, representam um avanço significativo rumo a eficiência.

Palavras-chave: Contraditório tridimensional, Fundamentação, Processo democrático, Novo código de processo civil

\begin{abstract}
Este trabajo pretende revisar olas del renovación del proceso, neoconstitucionalismo y el proceso democrático en el nuevo código de procedimiento civil. En este trabajo se utilizaron los métodos deductivos y dogmáticos y bibliográficos. Gracias-si proceso metodológico histórico y comparativo. La investigación se divide en tres partes: olas de renovación proceso, contradictorio tridimensional y democrática en nuevo código de Procedimiento Civil-NCPC. Actualmente la tercera ola renovatória el proceso trae nuevos temas que merecen consideración, entre ellos la NCPC, que consagra la aplicación de contradictorio en su visión tridimensional conocimiento-reacción-influencia. El derecho a un proceso de confrontación es el fundamento de las decisiones democráticas. La NCPC ha establecido parámetros para orientar

\footnotetext{
${ }^{1}$ Mestrando em Direito Público pela Fundação Mineira de Educação e Cultura - Universidade FUMEC, Minas Gerais, (Brasil). E-mail: marcosbianchini@hotmail.com

${ }^{2}$ Mestrando em Instituições Sociais, Direito e Democracia pela Fundação Mineira de Educação e Cultura Universidade FUMEC, Minas Gerais, (Brasil). Procurador da Câmara Municipal de São Gotardo, Minas Gerais, (Brasil). Professor pelo Centro de Ensino Superior de São Gotardo, Minas Gerais, (Brasil). E-mail: akbmp@hotmail.com
} 
la actividad judicial, establecer un núcleo mínimo contenido cuando la entrega de los juicios, positivando el razonamiento analítico, indispensable para el estado democrático de derecho y debido proceso, puesto que alcanzar uno de los ámbitos de las partes contradictorias, el derecho tridimensionales de influir en la decisión. Referido para razones del estado, así como para evitar la voluntad, en consonancia con el principio de eficiencia, mejorando y mejorando el derecho básico de la motivación judicial actúa, como el artículo 93, IX de la Constitución Federal. Todos estos desarrollos contribuyan en gran medida el proceso de democratización. Las ideologías del proceso democrático en la NCPC, añadido al principio de contradicción en su visión tridimensional, así como las razones legítimas y decisiones calificadas, representan un avance significativo hacia la eficiencia.

Keywords: Contradictorio tridimensional, Justificación, El proceso democrático, Nuevo código de procedimiento civil 


\section{INTRODUÇÃO}

Hoje, no direito processual civil, vige a tutela padrão constitucionalizada, consubstanciada na tutela processual civil (tutela base) e na tutela processual constitucional, de base empírica extremamente principiológica e fundante do ordenamento jurídico.

As ideologias contemporâneas de um ordenamento jurídico justo, com realização célere da justiça, pressupõem que cada vez mais o processo só tem razão de existir quando se está diante de direito lesado ou ameaçado. As transformações na sociedade atual, como a globalização, o desenvolvimento acelerado, a desigualdade social, refletem na apresentação de grandes diversidades nas relações sociais, de sorte a ocasionar um aumento considerável de conflitos e modificações no acesso à jurisdição.

Na concepção constitucional de processo, positivada no Novo Código de Processo Civil, o contraditório é aplicado na visão substantiva ou tridimensional, indo além do binômio conhecimento-reação, vedando a decisão surpresa e garantindo as partes o direito de influência no processo.

Pelo novo Código, o contraditório vincula não somente as partes, mas também ao juiz. Não se proferirá decisão contra uma das partes sem que ela seja previamente ouvida. É assegurada às partes paridade de tratamento em relação ao exercício de direitos e faculdades processuais, aos meios de defesa, aos ônus, aos deveres e à aplicação de sanções processuais, competindo ao juiz zelar pelo efetivo contraditório.

O juiz não pode decidir, em grau algum de jurisdição, com base em fundamento a respeito do qual não se tenha dado às partes oportunidade de se manifestar, ainda que se trate de matéria sobre a qual deva decidir de ofício.

A sentença de mérito será nula se proferida sem a integração do contraditório, quando esta deveria ser uniforme em relação a todos que deveriam ter integrado o processo; ou ineficaz, nos outros casos, apenas para os que não foram citados.

Antes os princípios eram considerados subsidiários, hoje, principalmente os constitucionais, deixaram de ser meros meios de integração do direito (frente às lacunas) e 
convertem-se em normas situadas no patamar mais elevado da ordem jurídica, aplicáveis em todos e quaisquer casos, bem como em todos as modalidades de processo.

O Novo Código de Processo Civil fixou parâmetros para nortear a atividade judicial, estabelecendo um núcleo mínimo de conteúdo quando da prolação de decisões judiciais (art.489), positivando a fundamentação qualificada, analítica ou legítima, indispensável ao estado democrático de direito e ao devido processo legal, uma vez que concretiza um dos escopos do contraditório tridimensional, qual seja, o direito das partes de influenciar a decisão.

Referida fundamentação, além de impedir o arbítrio, coaduna com o princípio da eficiência, que o Judiciário também está adstrito, aprimorando e qualificando o direito fundamental da motivação dos atos judiciais, previsto no artigo 93, inciso IX, da Constituição Federal de 1988.

O Novo Código de Processo Civil dissimulou a importância do mecanicismo da subsunção e do silogismo, resgatando a argumentação e a racionalidade prática. Em qualquer caso, o juiz deve sempre fundamentar sua decisão com argumentos responsáveis, desenvolvidos a partir da construção lógica e sistemática. É importante a justificação argumentativa de qualquer decisão judicial, com oferecimento da atividade estatal de jurisdição com transparência, como resultado de ação séria e responsável, evitando-se decisões aleatórias, teratológicas, injustas, incompreensíveis e principalmente, que cause prejuízo às partes e a sociedade.

Toda essa evolução contribui sobremaneira para a democratização do processo. Os métodos para a captação e processamento de informações com o objetivo de resolver os problemas investigados consistiram em analisar a realidade de maneira crítica, à luz de concepções teóricas com a finalidade de desenvolver a capacidade de observar, selecionar e organizar cientificamente os fatos da realidade.

Para a consecução de tal fim, utilizou-se os métodos dedutivo, dogmático e bibliográfico. Valeu-se do processo metodológico histórico e comparativo. 


\section{ONDAS RENOVATÓRIAS DO PROCESSO}

Hoje, no direito processual civil, vige a tutela padrão constitucionalizada, consubstanciada na tutela processual civil (tutela base) e na tutela processual constitucional, de base empírica extremamente principiológica e fundante do ordenamento jurídico.

As ideologias contemporâneas de um ordenamento jurídico justo ${ }^{3}$, com realização célere da justiça, pressupõem que o processo só tem razão de existir em razão da afirmação de direito lesado ou ameaçado em relação de direito material ${ }^{4}$.

As transformações na sociedade atual, como a globalização, o desenvolvimento acelerado e a desigualdade social, refletem na apresentação de grandes diversidades nas relações sociais, de sorte a ocasionar um aumento considerável de conflitos e modificações no acesso à jurisdição.

Nos idos de 1990, Ada Pelegrini, na famosa obra Tendências do Direito Processual, já advertia que sem pesquisas adequadas de estatística e de planejamento, há um descompasso entre o progresso científico do direito processual (doutrina e legislação) e a falta de infraestrutura e aperfeiçoamento do Poder Judiciário.

... é preciso reconhecer o grande descompasso entre a doutrina e a legislação de um lado, e a prática judiciária de outro. Ao extraordinário progresso científico da disciplina não correspondeu o aperfeiçoamento do aparelho judiciário e da administração da Justiça. A sobrecarga dos tribunais, a morosidade dos processos, seu custo, a burocratização da Justiça, certa complicação procedimental; a mentalidade do juiz, que deixa de fazer uso dos poderes que o Código lhe atribui; a falta de informação e de orientação para os detentores dos interesses em conflito; as deficiências do patrocínio gratuito, tudo leva à insuperável obstrução das vias de acesso à Justiça, e ao distanciamento cada vez maior entre o Judiciário e seus usuários. (GRINOVER, 1990, p. 177).

O Estado tem como um dos seus escopos a pacificação social dos conflitos, de maneira que o ordenamento jurídico constitucional incumbiu ao Poder Judiciário a tutela jurisdicional como meio de garantir aos cidadãos o acesso à jurisdição.

\footnotetext{
${ }^{3}$ Rodrigo Ramina aduz que processo justo e devido processo legal são postulados do processo enquanto um procedimento em contraditório. "Há casos em que a observância plena do devido processo legal pode não ser suficiente a proporcionar uma sentença justa; mas em todas as hipóteses que o princípio de devido processo legal for desrespeitado, a sentença, ao final produzida será inevitavelmente ilegítima” (LUCCA, 2015, p. 75).
} 
Porém, este acesso à jurisdição não tem o sentido de possibilidade de ingresso em juízo, sendo que é não se pode confundir acesso à justiça com acesso ao Judiciário. $\mathrm{O}$ acesso ao Judiciário está amparado no direito de petição, previsto no art. 50, XXXIV, „a", da Constituição de 1988, e no princípio da inafastabilidade da jurisdição (art. 5º XXXV da CR/88), relacionando-se com o direito de ação. Já o acesso à justiça está ligado ao deslinde da demanda, ou seja, o resultado do conflito, no sentido de viabilizar o acesso à ordem jurídica, significando efetivar a promoção da justiça.

Portanto, não se pode dizer que todo acesso à justiça passe necessariamente pelo acesso à jurisdição, uma vez que existem formas extrajudiciais de resolução de conflitos que podem se dar sem a intervenção estatal, os chamados sucedâneos da jurisdição.

Mauro Cappelletti e Bryant Garth salientam que a expressão "acesso à Justiça” é de difícil definição, mas serve para determinar duas finalidades básicas do sistema jurídico, quais sejam: deve ser igualmente acessível a todos e deve produzir resultados que sejam individual e socialmente justos.

O acesso à justiça, melhor identificado como acesso à jurisdição, oferece a mais ampla admissão de pessoas e causas ao processo (universalidade de jurisdição), garante o devido processo legal e assegura o princípio do contraditório e a efetividade de uma participação em diálogo, tudo isso com vistas a preparar uma solução que seja mais adequada às partes e capaz de eliminar todo resíduo de insatisfação, ou seja, garantir o acesso à justiça e à ordem jurídica justa (CINTRA; GRINOVER; DINAMARCO, 2007, p. 40).

Para haver um efetivo acesso à jurisdição, o sistema processual deve ser capaz de atender ao trinômio qualidade-tempestividade-efetividade.

Como se sabe, o Judiciário apresenta inúmeras mazelas, mas a demora da prestação jurisdicional, dificuldades envolvendo custas judiciais e honorários advocatícios, o formalismo do procedimento judicial, dentre outros, geram uma crise de confiança por parte dos cidadãos em relação ao Judiciário.

4 Em artigo publicado, Humberto Theodoro Jr. assevera que: "Sem o apoio em dados cientificamente pesquisados e analisados, a reforma legislativa dos procedimentos é pura inutilidade, que só serve para frustrar, ainda mais, os anseios da sociedade por uma profunda e inadiável modernização da Justiça. Sem estatística idônea, qualquer movimento reformista perde-se no empirismo e no desperdício de energias por resultados aleatórios e decepcionantes" (THEODORO JR, 2007, s/p). 
Neste cenário, segundo lecionam Mauro Cappelletti e Bryant Garth (1988), na busca do pleno acesso à ordem jurídica justa, adveio o movimento de acesso à justiça, ou às três ondas do acesso à justiça.

Referido movimento analisa e procura caminhos para superar as dificuldades ou obstáculos que fazem inacessíveis o acesso à justiça.

Salientam a existência de três obstáculos: o primeiro é o obstáculo econômico, isto é, a pobreza de muitas pessoas que pouco acesso tem à informação e à representação adequada; o segundo obstáculo é o organizacional, que se expressa nos chamados direitos e interesses (de grupo) difusos ou coletivos, nos quais o litigante individual seria o titular de insignificante fragmento do dano em questão; e o terceiro obstáculo é processual, no sentido de que o processo litigioso no Judiciário pode não ser o melhor caminho para ensejar a vindicação efetiva de direitos, de maneira que mister se faz reais alternativas aos juízos ordinários e aos procedimentos usuais.

Conforme se observa, o direito brasileiro foi capaz de criar mecanismos para garantir o pleno acesso à jurisdição (assistência judiciária gratuita, ação civil pública, mandado de segurança coletivo e ação popular).

Tendo cumprido as duas primeiras ondas renovatórias do Direito Processual, o direito brasileiro foi capaz de responder a uma questão extremamente relevante: a de se saber o que o Estado (aqui cabendo a utilização da denominação Estado-juiz, já que se trata do Estado no exercício da função jurisdicional) pode fazer para garantir o pleno acesso à justiça. Fica, todavia, uma pergunta ainda por responder: estará satisfeito o consumidor do serviço jurisdicional? Tal pergunta obriga o jurista a examinar a questão do acesso à justiça sob um novo enfoque. Não mais o enfoque do Estado, mas do consumidor do serviço judiciário, ou seja, o jurisdicionado. Surge, assim, a chamada "terceira onda", em que se busca o chamado "novo enfoque do acesso à justiça” (CÂMARA, 2011, p. 51).

Essa terceira onda é a que se vive hoje, sendo que merecem reflexão a reforma do judiciário, a deformalização dos procedimentos judiciais, a conciliação, a arbitragem, a mediação, o construtivismo jurídico na jurisprudência do Supremo Tribunal Federal (súmulas vinculantes, repercussão geral), ativismo judicial e principalmente, agora, o Novo Código de Processo Civil. 
O NCPC consolida sobremaneira a Era instrumentalista do processo, traz regras e princípios de modo a garantir o efetivo poder de influência das partes nos rumos do processo, sumarização de procedimentos, mitigação de recursos e meios de impugnação das decisões judiciais.

Em uma breve síntese, o novo CPC supera a ideologia liberal, individual e patrimonialista de processo, estabelecendo cooperação, boa-fé, efetividade e coletivização, tendo como legado a instituição do contraditório tridimensional e a fundamentação analítica das decisões. "O novo CPC implementa um sistema comparticipativo/cooperativo pautado nos direito fundamentais dos cidadãos e no qual todos os sujeitos processuais assumem responsabilidades e possibilidade de interlocução ativa" (THEODORO JR; NUNES; BAHIA; PEDRON, 2015, p. 20).

Conforme se observa, esta terceira onda centra sua atenção no conjunto geral de instituições e mecanismos, pessoas e procedimentos utilizados para processar e mesmo prevenir disputas nas sociedades modernas.

\section{PROCESSO DEMOCRÁTICO NO NOVO CÓDIGO DE PROCESSO CIVIL}

Pela dimensão substancial do contraditório, antes de proferida a decisão, todo fato sujeito a julgamento deve ter sido submetido ao contraditório. Deste modo, tem-se a vedação de prolação de decisão que cause surpresa as partes, ou seja, que haja decisão pautada em fatos e fundamentos que não tenham sido conhecidos pelos envolvidos no processo e que estes não tenham tido a oportunidade de se manifestarem sobre aqueles. Este visão substancial é de conteúdo mais abrangente do que a visão tradicional:

Do ponto de vista do seu conteúdo, o direito ao contraditório por muito tempo foi identificado com a simples bilateralidade da instância, dirigindo-se tão somente às partes. Dentro desse quadro histórico, o contraditório realizava-se apenas com a observância do binômio conhecimento-reação. Isto é, uma parte tinha o direito de conhecer as alegações feitas no processo pela outra e tinha o direito de querendo contrariá-las. Semelhante faculdade estendia-se igualmente à produção da prova. Trata-se de feição do contraditório própria à cultura do Estado Legislativo, confinando as partes no terreno das alegações de fato e da respectiva prova. Nessa linha, o órgão jurisdicional nada tinha que ver com a realização do direito ao contraditório, 
na medida em que apenas os litigantes seriam os seus destinatários". (MARINONI; ARENHART; MITIDIERO. 2015, pág.107).

A visão tradicional do princípio do contraditório aponta que dele "resultam duas exigências: a de se dar ciência aos réus da existência do processo, e aos litigantes de tudo o que nele se passa; e a de permitir-lhes que se manifestem, que apresentem suas razões, que se oponham à pretensão do adversário" (GONÇALVES, 2013, p.61)”.

Na concepção constitucional de processo, positivada no Novo Código de Processo Civil, o contraditório é aplicado na visão substantiva ou tridimensional, indo além do binômio conhecimento-reação, vedando a decisão surpresa e garantindo as partes o direito de influência no processo.

O princípio do contraditório pode ser decomposto em duas garantias: participação (audiência, comunicação, ciência) e possibilidade de influência na decisão.

A garantia da participação é a dimensão formal do princípio do contraditório. Trata-se da garantia de ser ouvido, de participar do processo, de ser comunicado, poder falar no processo. Esse é o conteúdo mínimo do princípio do contraditório e concretiza a visão tradicional a respeito do tema. De acordo com esse pensamento, o órgão jurisdicional efetiva a garantia do contraditório simplesmente ao dar ensejo à ouvida da parte.

Há, porém, ainda, a dimensão substancial do princípio do contraditório. Trata-se do poder de "influência". Não adianta permitir que a parte simplesmente participe do processo. Apenas isso não é suficiente para que se efetive o princípio do contraditório. É necessário que se permita que ela seja ouvida, é claro, mas em condições de poder influenciar a decisão do órgão jurisdicional.

Se não for conferida a possibilidade de a parte influenciar a decisão do órgão jurisdicional - e isso é o poder de influência, de interferir com argumentos, ideias, alegando fatos, a garantia do contraditório estará ferida. (DIDDIER JR., 2015, p. 79).

Como visto, pela faceta material do princípio do contraditório, às partes efetivamente deve-se possibilitar influenciar na decisão do julgador, seja em qualquer grau de jurisdição. Nenhuma decisão sobre um determinado ponto de fato ou de direito poderá ser exarada, ainda que se trate de fato novo ou não alegado pelas partes, sem que estas sobre referido ponto tenha sido oportunizada a possibilidade de manifestação. Referido direito de influência não se efetiva simplesmente ao dar possibilidade de a parte ser ouvida, mas haver reais condições de poder influenciar a decisão do magistrado. 
Pelo novo Código, o contraditório vincula não somente as partes, mas também o juiz.

É preciso esclarecer que a afirmação de que o juiz é sujeito do contraditório não quer significar que ele seja, a semelhança das partes, um contraditor que defenda interesses parciais. Juízes por exemplo não levam para o processo fatos não aventados pelos litigantes. Não é papel deles operar designando oficiosamente provas até como forma de preservar sua imparcialidade. São sujeitos na medida em que constrangidos pelo contraditório. Sujeitam-se ao contraditório, têm deveres que decorrem desse direito fundamental processual. Mais que mera "alface", o juiz de hoje assegura o contraditório substancial, vale dizer: i) é sua função provocar o debate para sanar dúvidas existentes, indicar e fomentar a exploração pelas partes de vias interpretativas não enfrentadas ou ainda não adequadamente aclaradas ou amadurecidas (terza via interpretativa); ii) compete-lhe prevenir as partes do perigo de frustração de seus pedidos pelo uso inadequado do processo; e iii) cabe-lhe consultar as partes antes de decidir sobre qualquer questão, mesmo que de ordem pública, assegurando a influência das manifestações delas na formação das decisões judiciais. Se o contraditório se reduzisse às partes o juiz poderia surpreender no momento decisório, algo impensável na atualidade. (NUNES; DELFINO, 2015, $\mathrm{s} / \mathrm{p})$.

As disposições positivadas no Codex testificam que não se proferirá decisão contra uma das partes sem que ela seja previamente ouvida (art. $\left.9^{\circ}\right)$. É assegurada às partes paridade de tratamento em relação ao exercício de direitos e faculdades processuais, aos meios de defesa, aos ônus, aos deveres e à aplicação de sanções processuais, competindo ao juiz zelar pelo efetivo contraditório $\left(\operatorname{art} .7^{\circ}\right)$. O juiz não pode decidir, em grau algum de jurisdição, com base em fundamento a respeito do qual não se tenha dado às partes oportunidade de se manifestar, ainda que se trate de matéria sobre a qual deva decidir de ofício (art.10). A sentença de mérito, quando proferida sem a integração do contraditório, será nula, se a decisão deveria ser uniforme em relação a todos que deveriam ter integrado o processo; ou ineficaz, nos outros casos, apenas para os que não foram citados (art.115).

Direito de influência. Atualmente, porém, a doutrina tem identificado no direito ao contraditório muito mais do que simples bilateralidade da instancia. Ao binômio conhecimento-reação tem-se oposto a ideia de cabal participação como núcleo-duro do direito ao contraditório. É lógico que o contraditório no processo civil do Estado Constitucional tem significado completamente diverso daquele que era atribuído à época do Estado Legislativo. Contraditório significa hoje conhecer e reagir, mas não só. Significa participar do processo e influir nos seus rumos. Isto é: direito de influência. Com essa nova dimensão, o direito ao contraditório deixou de ser algo cujos destinatários são tão somente as partes e começou a gravar igualmente o juiz. Daí a razão pela qual eloquentemente se observa que o juiz tem o dever não só de velar pelo contraditório entre as partes, mas fundamentalmente a ele também se submeter. O juiz encontra-se igualmente sujeito ao contraditório. (MARINONI; ARENHART; MITIDIERO, 2015, p.7-8). 
Pelo novo Código, a fundamentação é elemento estrutural da sentença e decorrência lógica do contraditório tridimensional.

O art. 93, IX da Constituição Federal, diz que toda as decisões serão fundamentadas, sob pena de nulidade. Embora a Constituição estabeleça necessidade de fundamentação, o Supremo Tribunal Federal entende que o acórdão ou decisão não precisam determinar o exame pormenorizado de cada uma das alegações ou provas, nem que sejam corretos os fundamentos da decisão ${ }^{5}$.

Assim, de acordo com o entendimento do STF, uma decisão omissa em relação a análise de todos os argumentos manejados pela parte vencida está suficientemente fundamentada nos termos do que determina a Constituição Federal.

No entanto, pelas disposições do novo Código de Processo Civil, o entendimento da Suprema Corte resta superado.

Releva consignar, que a doutrina critica a interpretação do Supremo, aduzindo que a Suprema Corte confunde motivação com fundamentação.

Essa premissa equivocada agora foi corrigida normativamente pelo Novo CPC, pois que este leva a sério o atual quadro de litigiosidade massiva que impõe aos juízes e, especialmente, aos Tribunais (em decorrência da força que a jurisprudência vem obtendo na práxis jurídica), analisar desde a primeira vez as questões (com destaque para as repetitivas) com amplo debate e levando a sério todos os argumentos para que, tais decisões e suas ratione decidendi, possam possuir a dimensão que necessitam. A ideia é de que se julgue bem das primeiras vezes, não sendo mais possível tolerar decisões superficiais que se repetem às centenas (ou milhares), permitindo idas e vindas, argumentos novos com assiduidade, instabilidade e anarquia decisória. É preciso otimizar o debate e o espaço-tempo processuais, gastando-os bem para que haja estabilidade, coerência e integridade na formação decisória (art. 926). E, com isso, não se poderia desconhecer, portanto, que a redução da fundamentação das decisões à mera motivação

\footnotetext{
5 “Questão de ordem. Agravo de Instrumento. Conversão em recurso extraordinário (CPC, art. 544, $\S \S 3^{\circ}$ e $4^{\circ}$ ). 2. Alegação de ofensa aos incisos XXXV e LX do art. $5^{\circ}$ e ao inciso IX do art. 93 da Constituição Federal. Inocorrência. 3. O art. 93, IX, da Constituição Federal exige que o acórdão ou decisão sejam fundamentados, ainda que sucintamente, sem determinar, contudo, o exame pormenorizado de cada uma das alegações ou provas, nem que sejam corretos os fundamentos da decisão. 4. Questão de ordem acolhida para reconhecer a repercussão geral, reafirmar a jurisprudência do Tribunal, negar provimento ao recurso e autorizar a adoção dos procedimentos relacionados à repercussão geral." (AI 791292 QO-RG, rel. Min. Gilmar Mendes, Publicação: 13/08/2010).
} 
pelo magistrado poderia tão somente reforçar, mais uma vez, a velha tese do "livre convencimento" do juiz, que, sob o argumento de decidir conforme a sua própria consciência, colocaria em risco não apenas a validade, mas a eficiência e legitimidade da decisão. (THEODORO JR; NUNES; BAHIA; PEDRON. 2015 p.307/308).

Dierle Nunes, Alexandre de Melo Franco Bahia e Flávio Pedron, no artigo intitulado "Precedentes no Novo CPC: é possível uma decisão correta?" (2015, s/p), traçam de maneira ímpar a diferença entre fundamentação e motivação:

...causa muito espanto juristas brasileiros criticarem o art. 489 do NCPC, principalmente seu $\S 1^{\circ}$. Ora, se não formos capazes de perceber que o exercício do princípio do contraditório e do princípio democrático somente se comprovam respeitados efetivamente no ato decisório, não seremos bem sucedidos no que concerne a separação satisfatória entre motivação (exercício solipsista da razão, ainda que com razões subjetivas) e fundamentação (pretensão normativa de construção de uma decisão em critérios socialmente validados e reconhecidos, portanto, em razões intersubjetivas). Desde muito o direito estrangeiro já compreendeu que a decisão judicial não pode ser fruto do ato de pensar solitário do magistrado. Mas somente comprova-se a coletivização da decisão de pudermos perceber nela a existência de uma pluralidade de vozes - as vozes da sociedade e as dos demais sujeitos do processo. Negar o art. 489 do NCPC é, lamentavelmente, comprometer-se novamente com a tradição do positivismo jurídico e deixar o ideal democrático escoar pelo ralo!

A razão parece estar com a doutrina. De acordo com o art. $489, \S 1^{\circ}$ do Novo CPC, quando a decisão judicial, seja ela interlocutória, sentença ou acórdão, se limitar a indicar, reproduzir ou parafrasear ato normativo sem indicar sua relação com a causa decidida, quando empregar conceitos jurídicos indeterminados sem explicar o motivo concreto de sua incidência no caso, quando invocar motivos genéricos, que se prestariam a justificar qualquer outra decisão, quando não enfrentar todos os argumentos deduzidos no processo capazes de, em tese, infirmar a conclusão adotada pelo julgador, quando se limitar a invocar precedente ou enunciado de súmula, sem identificar seus fundamentos determinantes nem demonstrar que o caso sob julgamento se ajusta àqueles fundamentos ou deixar de seguir enunciado de súmula, jurisprudência ou precedente invocado pela parte, sem demonstrar a existência de distinção no caso em julgamento ou a superação do entendimento, a decisão interlocutória, sentença ou acórdão, serão considerados pela lei como desprovidos de fundamentação.

Por sua vez, o art. 489, §2 , dispõe que no "caso de colisão entre normas, o juiz deve justificar o objeto e os critérios gerais da ponderação efetuada, enunciando as razões que 
autorizam a interferência na norma afastada e as premissas fáticas que fundamentam a conclusão".

O Novo Código de Processo Civil fixou parâmetros para nortear a atividade judicial, estabelecendo um núcleo mínimo de conteúdo quando da prolação de decisões judiciais, consagrando a fundamentação qualificada, analítica ou legítima, indispensável ao estado democrático de direito e ao devido processo legal, uma vez que concretiza um dos escopos do contraditório tridimensional, qual seja, o direito das partes de influenciar a decisão.

Referida fundamentação, além de impedir o arbítrio, coaduna com o princípio da eficiência, que o Judiciário também está adstrito, aprimorando e qualificando o direito fundamental da motivação dos atos judiciais, consagrado no artigo 93, inciso IX, da Constituição Federal de 1988.

O Novo Código de Processo Civil dissimulou a importância do mecanicismo da subsunção e do silogismo, resgatando a argumentação e a racionalidade prática. Em qualquer caso, o juiz deve sempre fundamentar sua decisão com argumentos responsáveis, desenvolvidos a partir da construção lógica e sistemática. É importante a justificação argumentativa de qualquer decisão judicial, com oferecimento da atividade estatal de jurisdição com transparência, como resultado de ação séria e responsável, evitando-se decisões aleatórias, teratológicas, injustas, incompreensíveis e principalmente, que cause prejuízos às partes e a sociedade.

Toda essa evolução contribui sobremaneira para a democratização do processo no novo Código de Processo Civil.

Mas o que é um processo democrático? Em interessante artigo publicado intitulado com esta indagação, Francisco José Borges Motta e Adalberto Narciso Hommerding, buscam a resposta, estabelecendo premissas de que o:

O processo é percebido como uma garantia contra o exercício ilegítimo de poderes públicos e privados em todos os campos (jurisdicional, administrativo, legislativo), com o fim de controlar os provimentos dos agentes políticos e garantir a legitimidade discursiva e democrática das decisões. Argumenta-se no sentido de que o estabelecimento de focos de centralidade (seja nas partes, seja no juiz) não se adapta ao perfil democrático dos Estados de direito da alta modernidade. Assume-se um paradigma procedimental de Estado Democrático de Direito, no qual se impõe a prevalência concomitante da soberania do povo e dos direitos fundamentais 
(cooriginários e reciprocamente constitutivos) em todos os campos, especialmente na esfera estatal. No âmbito jurisdicional, resgata-se a discussão entre todos os sujeitos processuais, sem privilégios a qualquer deles, mediante a implementação dos direitos fundamentais, que balizam a tomada de decisões em seu aspecto formal e substancial. Propõe-se a divisão da atuação entre as partes e os juízes, clarificando a sua interdependência, de modo a absorver os aspectos benéficos tanto dos movimentos liberais quanto dos sociais. Aposta-se na leitura do contraditório na modalidade de garantia de influência como referente constitucional do policentrismo e da comparticipação, em vista de que agrega, ao mesmo tempo, o exercício da autonomia pública e privada, tornando o cidadão simultaneamente autor e destinatário do provimento." (MOTTA; HOMMERDING, 2013, p.195-196).

Como antes os princípios eram considerados subsidiários, hoje, principalmente os constitucionais, deixaram de ser meros meios de integração do direito (frente às lacunas) e convertem-se em normas situadas no patamar mais elevado da ordem jurídica, aplicáveis em todos e quaisquer casos.

Por tudo isso, é indiscutível que o juiz, ao aplicar a lei ao caso concreto, ultrapassa o simples exercício de subsunção, exercendo uma função axiológica, por assim dizer. O juiz se vale tanto da norma posta como da tábua de valores existente no meio social (pautado em pressupostos éticos, morais e principiológicos), interando fato e norma, visando a solução mais justa para o caso concreto.

Os princípios, principalmente os constitucionais, deixaram de ser meros meios de integração do direito (frente às lacunas) e convertem-se em normas situadas no patamar mais elevado da ordem jurídica, aplicáveis em todos e quaisquer casos.

Princípio constitucional é o enunciado normativo que serve de vetor de interpretação. Propicia a unidade e a harmonia do ordenamento. Integra as diferentes partes da Constituição, atenuando tensões normativas. Quando examinado com visão de conjunto, confere coerência geral ao sistema, exercendo função dinamizadora e prospectiva, refletindo a sua força sobre todo o ordenamento. Apesar de veicular valores, não possui uma dimensão puramente axiológica, porque logra o status de norma jurídica. Violá-lo é tão grave como transgredir uma norma qualquer, pois não há gradação quanto ao nível de desrespeito a um bem jurídico. O interesse tutelado por uma norma é tão importante quanto aquele escudado em um princípio (BULOS, 2008, p.387).

Paulo Bonavides ensina que os princípios consagrados na Constituição estão alçados no ponto mais alto da escala normativa: 
Postos no ponto mais alto da escala normativa, eles mesmos, sendo normas, se tornam, doravante, as normas supremas do ordenamento. Servindo de pautas ou critérios por excelência para avaliação de todos os conteúdos normativos, os princípios, desde sua constitucionalização, que é ao mesmo passo, positivação no mais alto grau, recebem como instância valorativa máxima categoria constitucional, rodeada do prestígio e da hegemonia que se confere às normas inseridas na Lei das Leis. Com esta relevância adicional, os princípios se convertem igualmente em norma normarum, ou seja, normas das normas (BONAVIDES, 2014, p. 296).

O caráter normativo dos princípios dissimulou a importância do mecanicismo da subsunção e do silogismo, resgatando a argumentação e a racionalidade prática.

\begin{abstract}
Normas princípios: são as que indicam fins a serem alcançados ou valores a serem preservados. A dogmática jurídica atual reconhece que os princípios possuem normatividade. Propõe a construção de um Direito Constitucional principialista, em que as normas e os princípios não se postem como noções completamente antagônicas. Reconhece, contudo, que eles obedecem a diferentes graus de concretização. Assim, os princípios seriam normas jurídicas com um grau de generalidade relativamente elevado. Já as normas lograriam um espectro de ação muito mais reduzido do que os princípios (Esser). Da ótica da determinabilidade ou aplicação no caso concreto, os princípios demandariam um trabalho maior de concretização pela autoridade jurisdicional, enquanto a norma, cuja formulação seria menos vaga, não exigiria grande esforço (Larenz). Do ângulo do sistema das fontes do Direito, os princípios corroborariam normas de índole destacada na ordem jurídica em virtude de sua hierarquia dentro do sistema (Guastini). Os princípios seriam standards juridicamente vinculantes, que colimam reclamos de justiça, lastreando-se numa ideia de direito, enquanto as normas seriam vinculantes (Dworkin). (BULOS, 2001, p.37).
\end{abstract}

Aplicar a lei, de maneira simples e lógica, ganha novos contornos com o neoconstitucionalismo, uma vez que as normas constitucionais têm que ter aplicação máxima ${ }^{6}$. Neste cenário, os princípios assumem um papel preponderante, sendo que no caso concreto prevalecem sobre as regras. Portanto, a postura neoconstitucionalista inverte a lógica do sistema jurídico, justificando que se pode aplicar um princípio independentemente de haver uma regra, ou, contrario sensu, mesmo que exista uma regra dispondo de maneira diferente ${ }^{7}$.

Releva consignar que em qualquer caso, o juiz deve sempre fundamentar sua decisão com argumentos responsáveis, desenvolvidos a partir da construção lógica e sistemática. É importante a justificação argumentativa de qualquer decisão judicial, com oferecimento da atividade estatal de jurisdição com transparência, como resultado de ação séria e responsável, 
evitando-se decisões aleatórias, teratológicas, injustas, incompreensíveis e principalmente, que cause prejuízos às partes e a sociedade.

O princípio do equilíbrio é fundamental nas decisões eficientes, uma vez que o magistrado deve decidir o que é melhor para a sociedade.

A postura neoconstitucionalista incentiva o litígio, tendo em vista que não se pode afirmar com precisão qual é a regra que se aplica ao caso concreto. Saiu-se do mundo do império da lei para o mundo do império dos juízes, consequência natural de se adotar a postura neoconstitucionalista, na medida em que se aplica princípios em detrimento da lei. Vale lembrar que princípios são despidos de conteúdo uniforme, de modo que pode-se, perfeitamente, a título de exemplo, com base no princípio da dignidade da pessoa humana, se abarcar uma série de questões ${ }^{8}$.

A questão não é o que diz o princípio. A postura neoconstitucionalista inverte a lógica de aplicação do direito (analogia, costumes e os princípios gerais de direito) na medida em que se aplica um princípio independentemente de haver uma regra ou uma lacuna no direito.

Desta forma, há insegurança jurídica e incertezas. Não se pode afirmar com certeza qual é a regra que se aplicará ao caso concreto, ou se casos idênticos terão decisões semelhantes. A preocupação passa a ser com juiz que vai decidir (se é ou não proativo ou conservador) e não com o que diz a lei no caso concreto. Não se vislumbra na atuação jurisdicional um desestímulo a novas demandas, na medida em que pode-se recorrer ao judiciário mesmo que se esteja contra-legem, porque quando o juiz decide por princípios não está mais submetido à lei. Assim, o comportamento aético aflora. O Judiciário passa a ser utilizado por oportunistas. Descumprem-se contratos, viola-se a lei e aumenta-se a inadimplência.

\footnotetext{
${ }^{6}$ Com a adoção do modelo de Estado de Direito Democrático, o juiz atua com uma postura ativa, uma vez que o próprio direito material passou a depender de ações positivas. Essas últimas passaram a ser imprescindíveis para a prevenção dos direitos. Tudo isso, visando ao alargamento da ação protetiva dos direitos fundamentais.

7 Isto implica em dizer que todo e qualquer caso o juiz pode decidir da maneira que quiser, fundamentando sua decisão em um princípio, de modo que a lei passa a ser um argumento que pode ou não ser considerado no caso concreto.
} 
Neste cenário, a fundamentação analítica das decisões judiciais vai auxiliar na aplicação e interpretação direito, aumentando o grau de segurança e previsibilidade nas decisões judiciais, diminuindo os litígios e melhorando a qualidade da prestação jurisdicional, além de torná-la mais eficiente.

Contudo, para fazer isto o juiz deve fazer juízos de diagnose e prognose de uma dada regra, de modo que fundamentar adequadamente as decisões é fundamental para se garantir a função social do processo, bem como para se refletir sobre os custos e os benefícios da decisão judicial perante a coletividade e não apenas para as partes envolvidas no litígio.

O juiz deve ter em mente que as regras são para a sociedade e não para as partes. Assim, às situações semelhantes deve se aplicar o mesmo significado concreto.

Os escopos da função social do processo, traduzem segurança e previsibilidade na solução de conflitos pelo Judiciário.

O artigo $8^{\circ}$ do Novo Código de Processo Civil Brasileiro, testifica que ao aplicar a lei, o juiz atenderá aos fins sociais e às exigências do bem comum, resguardando e promovendo a dignidade da pessoa humana e observando a proporcionalidade, a razoabilidade, a legalidade, a publicidade e a eficiência.

Marinoni, Arenhart e Daniel Mitidiero, comentando o dispositivo em questão, ensinam que:

Fins sociais e bem comum. A identificação de finalidade exige a prévia identificação da função. Especificamente, a função do processo civil no Estado Constitucional. O processo civil serve para dar tutela aos direitos em uma dupla dimensão: prover justiça para o caso concreto e prover razões capazes de tornar o direito, a partir do caso concreto, menos indeterminado.

\footnotetext{
${ }^{8}$...já se decidiu que do direito à dignidade decorre o direito ao nome (que não encontra previsão expressa no texto da Constituição de 1988), conforme aduziu o STF: "O direito ao nome insere-se no conceito de dignidade da pessoa humana e traduz a sua identidade, a origem de sua ancestralidade, o reconhecimento da família, razão pela qual o estado de filiação é direito indisponível, em função do bem comum maior a proteger, derivado da própria força impositiva dos preceitos da ordem pública que regulam a matéria" (RE 248.869-1/SP, Rel. Min. Maurício Corrêa, DJ 12.03.2004, Ementário 2.143-4).

De outra parte, a dignidade da pessoa humana serviu para impedir o exame forçado de DNA por parte do pai presumido, posto que: "à luz do princípio da proporcionalidade ou da razoabilidade, impõe-se evitar a afronta à dignidade pessoal que, nas circunstâncias, a sua participação [do paciente] na perícia substantivaria" (STF, Rel. Min. Sepúlveda Pertence, DJ 15.05.1998, Ementário 1.910-1) (GANDRA MARTINS; MENDES; NASCIMENTO. 2012, p.646).
} 
Daí que a exigência de aplicação do ordenamento jurídico de acordo com os fins sociais e com as exigências do bem comum não pode significar outra coisa senão aplicação do ordenamento jurídico processual - que aqui nos interessa - sem o desvirtuamento de sua função. A subordinação da aplicação da ordem jurídica a fins sociais e ao bem comum, portanto, não importa previsão de fins outros que não aqueles assinalados pela sua função dentro do ordenamento jurídico ao processo civil. (MARINONI; ARENHART; MITIDIERO. 2015, p.105).

O Judiciário deve servir o povo e não os litigantes envolvidos na relação processual.

José Miguel Garcia Medina e Tereza Arruda Alvim Wambier asseveram que

o intérprete ao lançar as suas fundamentações, em sua decisão, não pode vincular o seu convencimento a respeito do acerto deste julgamento apenas às partes e aos Órgãos Jurisdicionais superiores. Ou seja, tem-se toda uma sociedade preocupada com o alcance dessa justiça que será entregue e como ela é administrada. (MEDINA; WAMBIER. 2013, p. 73-74).

Assim, as ideologias de processo democrático no Novo Código de Processo Civil, somadas ao princípio do contraditório em sua visão tridimensional, bem como a fundamentação legítima e qualificada das decisões, representam um avanço significativo rumo a eficiência.

\section{CONCLUSÃO}

O novo Código de Processo Civil supera a ideologia liberal, individual e patrimonialista de processo, estabelecendo cooperação, boa-fé, efetividade e coletivização, tendo como legado a instituição do contraditório tridimensional e a fundamentação analítica das decisões.

O Novo Código de Processo Civil fixou parâmetros para nortear a atividade judicial, estabelecendo um núcleo mínimo de conteúdo quando da prolação de decisões judiciais, consagrando a fundamentação qualificada, analítica ou legítima, indispensável ao estado democrático de direito e ao devido processo legal, uma vez que concretiza um dos escopos do contraditório tridimensional, qual seja, o direito das partes de influenciar a decisão.

Referida fundamentação, além de impedir o arbítrio, coaduna com o princípio da eficiência, que o Judiciário também está adstrito, aprimorando e qualificando o direito 
fundamental da motivação dos atos judiciais, consagrado no artigo 93, inciso IX, da Constituição Federal de 1988.

O Novo Código de Processo Civil dissimulou a importância do mecanicismo da subsunção e do silogismo, resgatando a argumentação e a racionalidade prática. Em qualquer caso, o juiz deve sempre fundamentar sua decisão com argumentos responsáveis, desenvolvidos a partir da construção lógica e sistemática.

É importante a justificação argumentativa de qualquer decisão judicial, com oferecimento da atividade estatal de jurisdição com transparência, como resultado de ação séria e responsável, evitando-se decisões aleatórias, teratológicas, injustas, incompreensíveis e principalmente, que cause prejuízos às partes e a sociedade.

O juiz deve ter em mente que as regras são para a sociedade e não para as partes. Assim, às situações semelhantes deve se aplicar o mesmo significado concreto.

Os escopos da função social do processo, traduzem segurança e previsibilidade na solução de conflitos pelo Judiciário.

Assim, as ideologias de processo democrático no Novo Código de Processo Civil, somadas ao princípio do contraditório em sua visão tridimensional, bem como a fundamentação legítima e qualificada da decisões, representam um avanço significativo rumo a eficiência.

\section{REFERENCIAS}

BAHIA, Alexandre de Melo Franco; NUNES, Dierle; PEDRON, Flávio. Precedentes no Novo CPC: é possível uma decisão correta? Disponível em: $<$ httphttp://genjuridico.com.br/2015/07/27/precedentes-no-novo-cpc-e-possivel-uma- decisaocorreta/\#_ftnref20>. Acesso em 03/08/2015.

BONAVIDES, Paulo. Curso de Direito Constitucional. 29 ed. São Paulo: Malheiros, 2014. BULOS, Uadi Lammêgo. Curso de Direito Constitucional. 2 ed. São Paulo: Saraiva, 2008. 
Constituição Federal anotada. São Paulo. 2a ed. São Paulo: Saraiva, 2001.

CÂMARA, Alexandre Freitas. Lições de direito processual civil. Vol. I. 21. ed. Rio de Janeiro: Lúmen Juris, 2011.

CAMBI, Eduardo. Neoconstitucionalismo e neoprocessualismo: direitos fundamentais, políticas públicas e protagonismo judiciário. $2^{\text {a }}$ ed. São Paulo. Revista dos Tribunais, 2011.

CANOTILHO, José Joaquim Gomes. Brancosos e interconstitucionalidade: Itinerários dos discursos sobre historicidade constitucional. Lisboa: Almedina, 2009.

CAPPELlETTI, Mauro, GARTH, Bryant. Acesso à Justiça. Tradução de Ellen Gracie Northfleet. Porto Alegre: Ed. Sérgio Antonio Fabris, 1988.

CARNELUTTI, Francesco. Sistema de Direito Processual Civil. v. 1. Trad. Hilomar Martins de Oliveira. São Paulo: Classic Book, 2000.

CHIOVENDA, Giuseppe. Instituições de Direito Processual Civil, v. 2. Trad. Paolo Capitanio. Campinas: Bookseller, 2000.

CINTRA, Antônio Carlos de Araújo; GRINOVER, Ada Pellegrini; DINAMARCO, Cândido Rangel. Teoria Geral do Processo. $23^{\circ}$ ed. São Paulo: Malheiros, 2007.

DIDIER, Jr. Fredie. Curso de Direito Processual Civil: Introdução ao direito processual civil e processo de conhecimento. Salvador: Jus Podivm, 2015.

GONÇAlVES, Marcus Vinícius Rios. Direito Processual Civil Esquematizado. $3^{\text {a }}$ Ed. São Paulo: Saraiva, 2013.

GOUVEA, Lúcio Grassi. Cognição Processual Civil: atividade dialética e cooperação intersubjetiva na busca da verdade real. In: DIDIER JR., Fedie (Org). Leituras Complementares de Processo Civil. 5a ed. Rev. Ampl. Salvador: Podium, 2007.

GRINOVER, Ada Pellegrini. Novas Tendências do Direito Processual, $2^{\mathrm{a}}$ edição, São Paulo: Forense Universitária, 1990.

LAKATOS, Eva Maria; MARCONI, Marina de Andrade. Metodologia Científica. 4. ed. São Paulo: Atlas, 2006. 
LAMY, Marcelo. A função jurisdicional e a criação do direito. Revista Brasileira de Direito Constitucional. RBDC n. 15, jan./jun, 2010.

LENZA, Pedro. Direito constitucional esquematizado. 16. ed. rev., atual. e ampl. São Paulo: Saraiva, 2012.

LUCCA, Rodrigo Ramina de. O dever de motivação das decisões judiciais. Salvador: Jus Podivm, 2015.

MARINONI, Luiz Guilherme. Teoria Geral do Processo. São Paulo: RT, 2006. MARINONI, Luiz Guilherme; ARENHART, Sérgio Cruz; MITIDIERO, Daniel. Novo Código de Processo Civil Comentado. São Paulo: Revista dos Tribunais, 2015.

MARTINS, Ives Gandra da Silva; MENDES, Gilmar Ferreira; NASCIMENTO, Carlos Valder do (Coords). Tratado de direito constitucional. V. 1. $2^{\mathrm{a}}$ ed. São Paulo: Saraiva, 2012.

MENDES, Gilmar Ferreira; BRANCO, Paulo Gustavo Gonet. Curso de direito constitucional. $7^{\text {a }}$ ed. rev. e atual. São Paulo: Saraiva, 2012.

MEDAUAR, Odete. A Processualidade no Direito Administrativo, $2^{\mathrm{a}}$ edição, revista, atualizada e ampliada. São Paulo: Revista dos Tribunais, 2008.

MEDINA, José Miguel Garcia; WAMBIER, Teresa Arruda Alvim. Parte Geral e Processo de Conhecimento (Processo Civil Moderno - v. 1). $3^{\text {a }}$ ed. São Paulo: Revista dos Tribunais, 2013.

MELLO, Celso Antônio Bandeira de. Curso de direito administrativo. $18^{\mathrm{a}}$ ed. São Paulo, Malheiros, 2005.

MORAES, Alexandre de. Constituição do Brasil Interpretada e legislação constitucional. $9^{a}$ ed. São Paulo, Atlas, 2013.

MOTTA, Francisco José Borges; HOMMERDING Adalberto Narciso. Que é um modelo democrático de processo? Revista do Ministério Público do RS, Porto Alegre, n. 73, jan. 2013 - abr. $2013 . \quad$ Disponível em: <http://www.amprs.org.br/arquivos/revista_artigo/arquivo_1383852047.pdf>. Acesso em 06/08/2015. 
NUNES, Dierle; DELFINO, Lúcio. Novo CPC: entre anarquia interpretativa, coerência e precedentes. Disponível em: <http://justificando.com/2014/08/21/novo-cpc-entre- anarquiainterpretativa-coerencia-e-precedentes/>. Acesso em 30/07/2015.

OLIVEIRA, Carlos Alberto Álvaro de. Garantia do Contraditório - Garantias Constitucionais do Processo Civil. Coord. José Rogério Cruz e Tucci. São Paulo: RT, 1999.

PIOVESAN, Flávia. Temas de Direitos Humanos. São Paulo: Max Limonad, 1998.

SARLET, Ingo Wolfgang. A eficácia dos direitos fundamentais. $5^{a}$ ed. Porto Alegre: Livraria do Advogado, 2005.

Dignidade da pessoa humana e direitos fundamentais na Constituição Federal de 1988. $9^{a}$ ed. Porto Alegre: Livraria do Advogado, 2011.

SARMENTO, Daniel. Livres e Iguais: Estudos de Direito Constitucional. Rio de Janeiro: Lumen Juris, 2007.

SOUZA, Carlos Aurélio Mota de. Motivação e Fundamentação das Decisões Judiciais e o Princípio da Segurança Jurídica. Revista Brasileira de Direito Constitucional. N. 7 jan./jun. 2006, Vol. 2.

SUNDFELD, Carlos Ari; MUÑOZ, Guillermo Andrés (Coords). As Leis de Processo Administrativo. São Paulo: Malheiros, 2000.

THEODORO JR, Humberto. Celeridade e efetividade da prestação jurisdicional: Insuficiência da reforma das leis processuais. Academia Brasileira de Direito Processual Civil. Disponível em $<$ http://www.abdpc.org.br/textos/artigos/Artigo\%2051\%20formatado.doc>. Acesso em $02 / 082015$.

THEODORO JR, Humberto; NUNES, Dierle; BAHIA, Alexandre de Melo Franco; PEDRON, Flávio. Novo CPC: Fundamentos e Sistematização. 2. ed. Rio de Janeiro: Forense, 2015.

WAMBIER, Teresa Arruda Alvim; CONCEIÇÃO, Maria Lúcia Lins; RIBEIRO, Leonardo Ferres da Silva; MELLO, Rogério Licastro Torres. Primeiros comentários ao Novo Código de Processo Civil - Artigo por artigo. São Paulo: RT, 2015. 